Article

\title{
Work and Family Life Reconciliation Policies in Turkey: Europeanisation or Ottomanisation?
}

\author{
Nazlı Kazanoğlu
}

School of Applied Social and Policy Sciences, Ulster University, Jordanstown Campus, Room 2D02 Shore Road, Newtownabbey BT37 0QB, UK; kazanoglu-n@ulster.ac.uk

Received: 28 November 2018; Accepted: 28 December 2018; Published: 28 January 2019

\begin{abstract}
This paper is an endeavour to explore and explain the Europeanisation patterns of gender equality in a longstanding candidate country, Turkey, with regard to the specific policy areas of work and family life reconciliation over the last two decades. To achieve this goal, this paper has utilised a combination of literature review, document analysis and 43 semi-structured in-depth interviews with European Union (EU) officials, representatives of social partners and international women's organisations, as well as Turkish political elites and representatives of civil society organisations. The collected data have been analysed through the thematic analysis research method. Relying on an extensive review of the related literature and policy documents together with the data collected, this paper contends that the process of Europeanising Turkish work and family life reconciliation policies has remained contradictory, incomplete and patchy. Although the Turkish government has made various legislative changes in response to the adaptational pressure coming from the EU, a closer examination of those legislative amendments indicates a continued disconnect between Turkey and the EU in the specific policy area of work and family life reconciliation.
\end{abstract}

Keywords: conditionality; defamilialisation; European Union; gender equality; Turkey; work and family life reconciliation

\section{Introduction}

The last quarter of the twentieth century saw an increase in the number of women entering higher education, a growing desire among women for self-development and a structural transformation of the labour market from industrialisation to deindustrialisation, which created relatively more flexible working conditions, an increased gap between living costs and income, and an increased economic necessity for families to have two incomes. All of these changes combined to alter the life paths of family members in general, but those of women in particular, and, concomitantly, the prevalent family model (Esping-Andersen 2009; Hemerijck 2013; Lewis 2009).

The traditional male breadwinner family model consists of a heterosexual married couple with children living under the same roof, where the husband is associated with an intense period of education, followed by uninterrupted full-time employment until retirement, while the wife dedicates her life to family altruism, acting as a 'domestic servant' (Esping-Andersen 2009, p. 27), This model has gradually lost some of its social prevalence, with other family models, such as the adult earner family model, or one-and-a-half-earner family model, gaining more prominence (Esping-Andersen 2009; Hantrais 2004; Lewis 1992). These changes have been reflected in changing gender roles, particularly the roles of women. Since the early 1980s, women have come to be associated both with both home-making and with life-long employment (McDonald 2000; McGlynn 2005). Their labour force participation has become relatively more continuous, even among mothers of small children. They remain in the labour market and contribute to the family budget, though with considerable cross-national variations (Esping-Andersen 2009; Hemerijck 2013; Lewis 2009). This transformation 
has been viewed as an improvement in terms of women's status within society. In pursuing a shift from primarily 'home-making' to 'life-long employment', they could be freed from dependency upon either their fathers or male breadwinner partners. Hence, this shift was seen as a solution to a series of problems. However, it has also been argued that it exacerbated existing social risks and inequalities, and even created new ones (Esping-Andersen 2009; Hemerijck 2013). Since the main aim of social policy-making is to provide for human wellbeing and increase individual quality of life (Taylor-Gooby 1996), these transformations have successfully led to the formulation of laws and policies, so that work and family life reconciliation has become more prominent than ever before, especially at the European Union (EU) level. From the 1980s onwards, the EU has prepared numerous strategies, formulated different goals and targets, drafted legislation and introduced various initiatives and roadmaps regarding work and family life reconciliation. Although the issue remained under the domain of member and candidate states for a very long time, since the early $2000 \mathrm{~s}^{1}$, EU documents have started requiring a convergence from the member, and especially from the candidate, states.

Turkey, which has long sought to gain official EU membership status (Aybars and Tsarouhas 2010), has been subject to these relatively stronger integration and adaptation requirements in terms of work and family life reconciliation. Low female employment rates, the suppressed position of women within the labour market, the lack of reconciliation measures and poor early childhood education and care have always been EU points of concern when assessing Turkey's membership status (Aldikacti-Marshall 2013). Hence, they have occupied a significant space in Turkey's Accession Partnership Documents ${ }^{2}$. Almost all, but particularly the second and third, have openly highlighted the incompatibilities between the Turkish Labour Code and EU legislation with respect to work and family life reconciliation. This has compelled Turkey to construct a new Labour Code (Aldikacti-Marshall 2013), that needs to include complementary directives related to parental leave, childcare facilities and working time arrangements (European Commission 2003). Turkey has a long way to go to adapt these changes. The conservative social order in Turkey has historically kept alive the gendered division of labour, which holds women accountable for domestic work and men responsible for earning a living (Dedeoglu 2012). Nevertheless, it is plausible to argue that the EU, and EU candidacy, has had a marked influence on Turkey's reconciliation of work and family life policy development. The Turkish government has successively introduced various laws and bylaws regarding parental leaves, childcare provisions and working time arrangements (ibid., 2012). However, more recently, as the Justice and Development Party (Adalet ve Kalkinma Partisi, AKP) has gradually increased its share of the national votes from $34.26 \%$ to $46.58 \%$ in 2007 to $49.9 \%$ in 2011's general elections and thus guaranteed its place within society, the Turkish socio-political discourse began to change rapidly (Akser and Baybars-Hawks 2012). In this new phase of AKP governance, its Islamic background has become more visible and the party has started to push its Islamic values on the public more than it had before. Arguably, in the AKP's second tenure, Turkish foreign policy has taken a dramatic turn and Turkey has looked more to the East than the West. The new vision of the AKP government was to give Turkey a major role in the unanimity of Islamic countries and to hold a prominent position in the Muslim world (ibid., 2012), which has clearly effected Turkey's Europeanisation process, especially with respect to the reconciliation of work and family life. A closer examination of the laws, regulations and administrative provisions that Turkey has passed throughout its Europeanisation process clearly

1 Particularly during the 2000s, the coordination method of governance became more common in the EU. Unlike the community and intergovernmental methods, it offers middle ground solutions and seeks voluntary cooperation among member states or, at least, to decrease member states' reluctance with regard to transferring their policies to the EU level and/or adopting EU-level policies to their national level (Borras and Jacobsson 2004; Vural 2011). Rather than finding 'one size fits all' solutions to policy problems, this method aims at finding the best solution through practice exchanges among the member states (Kantola 2010).

2 An official EU document prepared by the European Commission that identifies the reforms needed to be done at the domestic level in order to align the domestic legislative structure to the EU Acquis, together with the financial or technical aid provided by the EU to the applicant country for the reforms (Aldikacti-Marshall 2013; Aydin-Duzgit and Tocci 2015). 
indicates an incomplete and highly contradictory attitude regarding work and family life reconciliation instruments. It has implicitly reproduced the gendered division of labour and emphasised women's supremacy in the familial sphere.

The present paper thus seeks to examine the Europeanisation patterns of Turkey, whose Europeanisation process has been subject to various ebbs and flows, in the specific policy area of work and family life reconciliation, from a critical gender lens. More precisely, this is an attempt to explore whether and to what extent Turkey has accommodated its work and family life reconciliation legislative framework to the EU, and to map the reconciliation provision deficits in Turkey. The paper therefore starts with introducing the theoretical framework. Second, it outlines the work and family life reconciliation model prior to official EU candidacy. Then, it moves on to exploring the legislative changes favoured by Turkey under the influence of the EU. Finally, it illustrates the contradictory and incomplete elements within the legislative changes made under EU influence.

The empirical data used in this paper draws on analysis of the findings from semi-structured interviews conducted as part of the author's doctoral dissertation on the Europeanisation patterns of work and family life reconciliation policies in Germany and Turkey. Forty-three interviews were conducted with (a) EU officials, as well as representatives of the EU social partners and international women's organisations in order to obtain the EU's views on Turkey, and (b) representatives of women's structures, such as the corresponding women's organisations and lobby groups located in various cities in Turkey, as well as the political elites, including the former and current Family and Social Policy ministers and the representatives of women's branches of political parties, especially the ruling and oppositional parties, to understand their contribution to the work and family life reconciliation policy-(re)making process. All interviews were conducted between January 2017 and April 2017. The collected data has been analysed via the thematic analysis research method.

\section{Theoretical Framework}

This paper draws on two crucial aspects in terms of theoretical basis: (a) conditionality and (b) defamilialisation. The first stems from the context of EU enlargement and the desire of most Central and Eastern European countries to join the EU (Schimmelfennig and Sedelmeier 2005). The second originates from the feminist critiques of Esping-Andersen (1990) path-breaking welfare regime typology, differentiating reconciliation arrangements on the basis of whether and to what extent they encourage women's employment. The term conditionality is applied here when explaining the ways in which the EU has influenced Turkey in terms of work and family life reconciliation policy-(re)making, while defamilialisation is applied when illustrating the work and family life reconciliation policy paradigm.

Conditionality - a concept rather than a theory — has been used within Europeanisation literature in order to explain the Europeanisation processes of candidate countries (Grabbe 2003). In a nutshell, this is a process wherein a candidate country tries officially to convince the EU that it is ready to feature EU laws, regulations, norms and values at the domestic level. Featuring EU laws, regulations, norms and values undoubtably leads to a move, at the domestic level, from internal standards towards EU standards. Therefore, it could be argued that conditionality triggers a Europeanisation process in candidate countries. The process actually starts when the applicant country decides to apply for membership, but official status is achieved when the European Council recognises and declares this candidacy (Aydin-Duzgit and Tocci 2015). To do so, the Council expects the applicant country to fulfil the so-called Copenhagen Criteria $^{3}$ (ibid., 2015) and determines the country's readiness for

3 The Copenhagen criteria are the rules and laws that the country needs to obey and implement in order to be eligible to join the European Union. They can be summarized, as (1) guaranteeing democracy and ensuring the protection of human rights and minority rights, (2) a functioning market economy and being able to cope with competitive pressure and market forces within the EU, (3) being able to take on the obligations of membership and being able to implement the EU Acquis (Retrieved from: http://eur-lex.europa.eu/summary/glossary/accession_criteria_copenhague.html). 
full membership (Aldikacti-Marshall 2013). Once the Council officially recognises and declares the candidacy status, the Europeanisation process officially begins. After this, the applicant country starts receiving 'Accession Partnership Documents ${ }^{4}$, which is followed by the applicant country drawing up a detailed action programme for the adoption of the EU Acquis ${ }^{5}$. The Commission then reviews those 'National Program for the Adoption of the Acquis' documents and transmits its thoughts on the proposed reforms, in terms of compliance with the EU Acquis, to the applicant country through annual 'Progress Reports' (Aldikacti-Marshall 2013). It is important to note that Europeanisation does not only matter in terms of the changes that take place in the administrative and legislative structures of national governments, but also in terms of the extent to which the national states feel "European", as Liebert (2003) points out. That is to say that Europeanisation also includes the transmission of the rationale behind the policy-making. This links to the second aspect of the theoretical framework: defamilialisation (Esping-Andersen 1999).

In developing his welfare regime typology, Esping-Andersen (1990) defined regimes on the basis of different welfare distribution arrangements between the family, the market and the state ${ }^{6}$. He argues that three complementary welfare pillars work simultaneously in order to provide human welfare (see Figure 1 below), and different countries lean on different entities for different welfare needs.

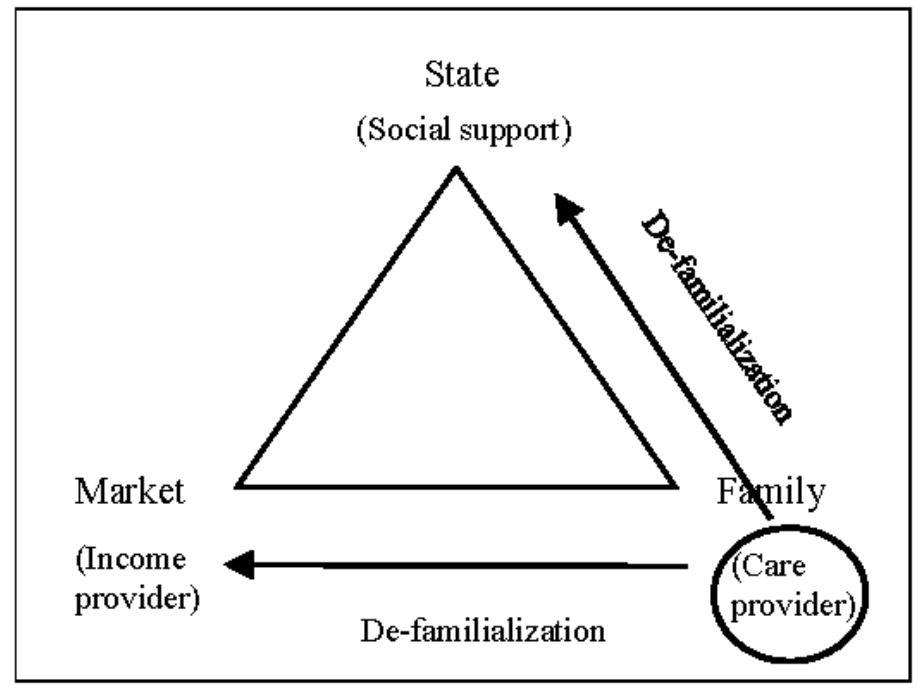

Figure 1. Distribution of welfare between market, family and the state.

For example, while Mediterranean countries rely on the family for care provision and the state comes into play only after the family's capacity for care provision is exhausted, Scandinavian countries pre-emptively hand the reins over either to the market or to the state. Theoretically, the former exemplifies a familialised arrangement, whereas the latter represents a defamilialised one. Since Esping-Andersen developed his welfare regime typology, the distinction between familialisation and defamilialisation has been used to define the level of state or market support in relaxing families' care responsibilities. In that sense, familialisation is used to denote producing or reproducing a welfare

4 An official EU document prepared by the European Commission that identifies the reforms needed to be done at the domestic level in order to align the domestic legislative structure to the EU Acquis, as well as the financial or technical aid provided by the EU to the applicant country for the reforms.

5 Acquis refers to all the EU rules, standards and policies (Retrieved from: http://eur-lex.europa.eu/summary/glossary/ accession_criteria_copenhague.html).

6 In his book, Three Worlds of Welfare Capitalism, Esping-Andersen excludes the distribution of care provisions from his typology and focuses more on the relationship between market and the state. He has thus been criticised from various perspectives, especially from feminist scholars. These criticisms have been acknowledged by Esping-Andersen, and when revisiting the welfare typology, he included the care arrangements into his study (see Esping-Andersen 1999; Lewis and Ostner 1991; Orloff 1993; O'Connor 1993). 
model wherein the family is the main care provider. On the other hand, defamilialisation denotes a curtailment of individual welfare dependence on kinship. Although Esping-Andersen himself, and notable feminist scholars, use the term in a broader comparison of welfare regimes, this paper applies it solely to work and family life reconciliation arrangements as the central aim is to tease out the Europeanisation process of Turkish work and family life reconciliation policies. With respect to work and family life reconciliation arrangements, familialisation means assigning a greater share of domestic duties, in particular care responsibility, to families, whereas defamilialisation means transferring domestic obligations from the private sphere of the family to the public sphere. More precisely, familialised reconciliation policies help women by easing their work responsibilities and provide them a greater amount of time to spend with their families and defamilialised reconciliation policies seek to encourage women to participate in the labour market by alleviating their care obligations (Esping-Andersen 1999; Leira 2002; Lohmann and Zagel 2016).

By combining conditionality with defamilialisation, this paper aims to provide an opportunity to push the boundaries of existing theories in the field of Europeanisation studies, moving the scope of the discussion beyond the EU influence at the policy level.

\section{Work and Family Life Reconciliation Policies in Turkey before the Helsinki Summit ${ }^{7}$}

While EU candidacy has had a marked influence on Turkey's reconciliation of work and family life policy development, it is important to look at this in the context of the situation pre-EU candidacy (Liebert 2003), in order to highlight the change brought about by the influence of the EU.

In the early Republican era, under the influence of Ziya Gokalp ${ }^{8}$, Turkey's first president Ataturk and his followers pursued a very busy reform agenda 9 based on Western standards (Arat 2012). However, these reforms all took place in the public sphere and left the family sphere untouched (Pateman 1989). Therefore, Turkey continued employing the family and kin solidarity family model, which expects women to be the full-time care-providers for family members and men to be the full-time breadwinners of the family (Ferrera 1996; Grutjen 2008). In addition to this family and kin solidarity model, the Ottoman Empire's heritage and the strong traces of Islam created a highly conservative social order in Turkey, resulting in a very low level of defamilialisation in work and family life reconciliation policies.

To begin with, family leave provisions in Turkey before the introduction of the new Labour Code in 2003 were very immature, and far removed from EU standards. The 1971 Labour Code granted female employees, who were working in public sector, six weeks before and six weeks after the delivery of the child, making a total of twelve weeks of paid maternity leave (Labour Code 1971, Article 70), with the right to ask for six months of unpaid parental leave after giving birth. There was a clear distinction between the public and private sectors with respect to job protection. While women working in the

7 In 1999, at the Helsinki Summit, the EU declared Turkey an official candidate state (Aldikacti-Marshall 2013). Afterwards, a mutual but hierarchical exchange period commenced between the EU and Turkey. The EU started sending 'to-do lists' for Turkey, under the name of the 'Accession Partnership Documents', wherein the EU outlines the administrative and legislative amendments Turkey had to make to attain official membership (ibid.). As a response to these official documents, the Turkish government has introduced a number of laws and bylaws, in line with those of the EU, with respect to leave schemes, childcare provision and working time arrangements (Aldikacti-Marshall 2013; Dedeoglu 2012; Ilkkaracan 2010). In other words, it can be said that a Europeanisation process has started in Turkey. Therefore, this paper accepts the Helsinki Summit as a historical marker and explores the period between 1999-2017.

8 Ziya Gokalp, a Turkish political philosopher, developed a concept called "Turkish-Islamist-Westernist Modernism" and supported combining the technological and scientific innovations, as well the civilized values and norms of the West, with Islam. Gokalp advocated building a new Turkish nationality based on this synthesis (Arat 2012).

9 The first Civil Code of the Turkish Republic came into force in 1926 and abolished polygamous marriages and husband's rights on one-sided divorce. It also legalised monogamous marriages and gave the rights of divorce, child custody and ownership of family properties both to men and women. Moreover, women gained the right of suffrage in 1934, primitive maternal leave rights were introduced in 1945, the Law on Family Planning legalised the sale and free dissemination of contraception in 1965 and the same law legalised abortion until the 10th week. Unfortunately, the concept of "head of family", given to fathers, was not abolished until the introduction of new Civil Law in 2001 (Aldikacti-Marshall 2013; Bugra and Keyder 2006; Bugra and Cakar 2010; Dedeoglu 2012). 
public sector were guaranteed job protection until the end of their maternity leave, women employed in the private sector did not have any guaranteed protection from dismissal. The employer had the right to dismiss the worker without notice. According to the Labour Law of 1971, only fathers employed in public sector were entitled to a (three to ten days) legal parental leave. The Code did not include any reference to paternity or parental leaves of fathers working in the private sector (Aldikacti-Marshall 2013). Rules and regulations regarding their leave were totally left to companies' initiatives. This reflected the perception, in the Turkish social context, that it was not appropriate for fathers to be involved in domestic work.

In 1987, after almost fifteen years of stagnation in terms of reconciliation measures, the Turkish Ministry of Labour and Social Security introduced an official bylaw regarding the working conditions of pregnant or breastfeeding female employees, as well as nursing room and care centre provisions. The bylaw required companies employing more than 150 female workers to provide comprehensive nursery rooms, and companies employing more than 300 female workers to provide comprehensive childcare centres and pre-school facilities (Bakirci 2010). Unlike most other European countries, Turkey did not provide any legal right to children in terms of childcare place enrolment.

Another cornerstone of work and family reconciliation, working time arrangements, were also highly disappointing in Turkey before the Helsinki Summit. Labour Act No. 1475 covered neither part-time employment nor fixed-term employment. Although the majority of women were working part-time in order to be able to reconcile their work and family lives, part-time or fixed-term employment policies were lacking. In the absence of legal policies with respect to working time arrangements, part-time workers were working with no job guarantees, predominantly low wages and limited opportunity for progression. In essence, those kinds of jobs were regarded as secondary and informal jobs (Dedeoglu 2012).

All in all, the Turkish reconciliation model prior to the Helsinki Summit clearly maximised women's domestic responsibilities and fed into their prioritisation within the familial sphere (Bugra and Keyder 2006; Dedeoglu 2012). Turkish legislation with respect to work and family life reconciliation, prior to Turkey's official EU candidacy, therefore failed to transfer care provisions from family to either market or to state, which is in accordance with a high level of familialisation and low level of defamilialisation.

\section{Europeanisation of Turkish Work and Family Life Reconciliation Policies}

When assessing Turkey's work and family life reconciliation measures, the EU and EU-related institutions focused on three interrelated aspects. As can also be seen from Table 1 below, these were low female employment rates, underdeveloped work and family life reconciliation measures and poor early childhood education and care (Aldikacti-Marshall 2013; Bakirci 2010).

Table 1. EU requirements on Turkey.

\begin{tabular}{cl}
\hline \multicolumn{1}{c}{ Document: } & \multicolumn{1}{c}{ Content: } \\
\hline Accession Partnership Document, 2001 & $\begin{array}{l}\text { Remove remaining forms of discrimination against women and all } \\
\text { forms of discrimination on the grounds of sex, racial or ethnic } \\
\text { origin, religion or belief, disability, age or sexual orientation } \\
\text { (Employment and social affairs: } 8) .\end{array}$ \\
\hline & $\begin{array}{l}\text { Adopt a transposition programme of the Acquis in the areas of } \\
\text { labour law, equal treatment for women and men, health and safety } \\
\text { at work, the fight against discrimination, and public health. } \\
\text { Develop a yearly plan for financing investment, based on a } \\
\text { realistic assessment of costs of alignment and of available public } \\
\text { and private resources (Employment and social affairs: 8 and 9). }\end{array}$ \\
\hline
\end{tabular}


Table 1. Cont.

Document:

Progress Report, 2005

Accession Partnership Document, 2008

Progress Report, 2009

Progress Report, 2010

Progress Report, 2012

Progress Report, 2015

\section{Content:}

... Turkey has not accepted the Article 8 of the European Social Charter on maternity leave of working women yet (p. 38).

... In the last four years, Turkey made a $68 \%$ increase in the number of children in pre-school education yet it is still low ... There is still much to be done in this area (p. 137).

Address labour market imbalances. To this end, improve incentive structures and flexibility in the labour market to increase participation and employment rates; improve education and professional training efforts, thereby encouraging the shift from agriculture to a service-based economy (Economic criteria: 7).

... However, gender equality remains a major challenge in Turkey. According to official statistics, participation by women in the labour force is low (24.8\% in 2007), and on a decreasing trend. The rate of women's employment is the lowest among the EU Member States and the OECD countries (p. 20).

... As regards women's participation in the labour market, the absence of sufficient child-care facilities and the existence of stereotypes all contribute to this (p. 25).

... There has been no progress in measures on improving the work-life balance are not fully in place, and the existing ones mainly focus on women rather than a gender mainstreaming approach ... Provision of childcare facilities for working women remained an issue; work on a regulation on parental leave did not proceed (pp. 26 and 65).

... In the field of equal opportunities, there is no progress in increasing women's low participation rate in the labour force. The lack of institutions to care for children, the elderly and the sick hinders women's employment and reinforces their role as carers ... The legislation and policies on balance of work and private life need take into account gender equality (p. 52).

Alongside the official documents listed in Table 1, low female employment rates and work and family life reconciliation provision deficits have been repeatedly criticised by different official EU representatives while discussing Turkish work and family life reconciliation measures. A senior policy expert from one of the EU social institutions has stated that:

"... we try to support and defend Turkey as much as we can but sometimes it becomes impossible ... female employment for example is such a sphere that we can't really defend Turkey ... I don't remember the official statistics but it's below $25 \%$ so how can you really say something positive about Turkey on this? I mean it's a fact ... a very negative one ..."

Likewise, a senior member of the Justice, Consumers and Gender Equality Commission has argued:

"... unfortunately I can't see any progress in Turkey since I joined this commission ... Of course there are more serious topics ... I mean half of the civil servants are imprisoned ... But female employment is a technical topic and Turkey had to increase the rate maybe 15 years ago ... "

Moreover, a senior expert from one of the social partners argued:

“... Well, Turkey ... not good I'd say ... in any sense ... Yes, Turkey needs work and family life reconciliation measures ... Turkey needs more women in the labour market ... For all these Turkey needs a clear mind-set change..." 
Another highly contested aspect of Turkish work and family life reconciliation policies was the privately-run childcare provision. Many official EU representatives stubbornly emphasised the very high fees of private childcare facilities in Turkey. They argued that the fees that Turkish parents need to pay to register their children at a childcare facility are so high that they prefer familial childcare. While discussing Turkish childcare provisions with a policy advisor from one of the social partners, who has three Turkish members, it was mentioned that:

"... I know from our member organisations that one of the biggest problem in Turkey is the private kindergartens ... They are so expensive ... here we try to raise awareness and make some advocacy activities for free public childcare, there in Turkey our member organisations are saying that the prizes are almost as equal as mothers' wages ... It is unbelievable ..."

All in all, as can be seen from the several examples above, the EU has constantly highlighted Turkey's scarce reconciliation measures. In response, Turkey welcomed those above-mentioned EU requirements and agreed to adopt a number of reforms with respect to parental leave, childcare provisions and working time arrangements (Yilmaz 2016). As Table 2 shows, only three years after gaining official candidacy status, the Turkish government made its first move in Europeanising its work and family life reconciliation model, which controversially continued with ups and downs until 2017 (Ilkkaracan 2010).

It is fair to consider passage of these laws as outstanding steps towards Europeanising the Turkish work and family life reconciliation model. After an almost eighty-year commitment to work/care dualism-focused social policies, and prosaic work and family life reconciliation policy making, Turkey started introducing measures which would alleviate the work and family life conflict (Dedeoglu 2012; Ecevit 2010). The overall picture regarding these legislative amendments indicates a social policy transformation that has led to an upgrade and widening in work and family life reconciliation policies. There are shorter periods of leave endowing both mothers and fathers alike with targets set to expand the public childcare provision, and tax reductions are available to newly established childcare centers, indicate doubts about the strong adherence to the traditional male breadwinner family model. In other words, conservative gender roles maximising women's domestic responsibilities and supporting them to stay at home and care for their family members had begun to evaporate. Turkey has come a long way in terms of Europeanising its work and family life reconciliation policies. Through unburdening women's familial obligations, the Turkish government tended to ease women's entry into the labour market, and also provided some policy tools that would help them to remain in the labour market. Theoretically speaking, under EU influence between 1999 and 2017, Turkey experienced an intense process of defamilialising its work and family life reconciliation policies (Esping-Andersen 1999). Yet, that is not to say that Turkey has pursued a fully-fledged Europeanisation in this specific policy area.

The Turkish government, while passing defamilialised reconciliation laws, has also continued passing familialised reconciliation laws. The Turkish work and family life reconciliation framework, therefore, continued to show fits and starts with the EU and made the Europeanisation process somewhat unclear. This paper therefore, proceeds with an illustration of those unclear notions. 
Table 2. Europeanisation of work and family life reconciliation policies in Turkey.

\begin{tabular}{|c|c|}
\hline Directive: & Content: \\
\hline Labour Code 2003 (article 74) & $\begin{array}{l}\text { The law guaranteed pregnant woman a total of } 16 \\
\text { weeks paid leave with protection from dismissal and } \\
\text { the right to return to the same or equivalent position. } \\
\text { It also provided nursing employees a total of } 1.5 \\
\text { hours of nursing time after the leave, to be treated as } \\
\text { part of her daily working time. }\end{array}$ \\
\hline Labour Code 2003 (article 88) & $\begin{array}{l}\text { The law obliged companies employing } 100 \text { to } 150 \\
\text { female workers to provide comprehensive nursery } \\
\text { rooms, and companies employing more than } 150 \\
\text { female workers to provide comprehensive childcare } \\
\text { centres and pre-school facilities. }\end{array}$ \\
\hline Labour Code 2003 (article 13) & $\begin{array}{l}\text { The law ensured equal treatment between part-time } \\
\text { and full-time workers. }\end{array}$ \\
\hline Municipal Code 2005 (article 14) & $\begin{array}{l}\text { The law obliged metropolitan municipalities and } \\
\text { municipalities with a population over 50,000 to } \\
\text { provide children's care centres. }{ }^{10}\end{array}$ \\
\hline Strategic Plan of the Ministry of Education (2009) & $\begin{array}{l}\text { The plan set a national target of raising the childcare } \\
\text { enrolment rate for the 3-5 age group above } 70 \% \text {. }\end{array}$ \\
\hline 10th Development Plan (2014-2018) & $\begin{array}{l}\text { The plan set the target of increasing the preschool } \\
\text { enrolment rate for the } 4-5 \text { age group from } 47 \% \text { in } \\
2013 \text { to } 70 \% \text { as of } 2018 \text {. }\end{array}$ \\
\hline $\begin{array}{l}\text { Family and Dynamic Population Structure Protection } \\
\text { Plan (2015) }\end{array}$ & $\begin{array}{l}\text { The plan introduced the right to paid part-time } \\
\text { maternal leave for employed mothers for the first six } \\
\text { months following the end of the maternal leave. It } \\
\text { also provided parents the right to flexible working } \\
\text { arrangements until their children reach mandatory } \\
\text { school age ( } 5.5 \text { years old). It also introduced a } \\
\text { five-year tax reduction for newly established } \\
\text { childcare centres ran by the Ministry of Family and } \\
\text { Social Policy }{ }^{11} \text { and expanded the share of the } \\
\text { government budget for elderly care (Retrieved from: } \\
\text { http://www.ensonhaber.com/aile-paketi- } \\
\text { yururluge-girdi-2015-04-27.html). }\end{array}$ \\
\hline Reform on Labour Code 2003 (article 74:2) & 10-day long unpaid paternity leave to fathers. \\
\hline
\end{tabular}

\section{Puzzling Notions within the Legislative Reforms}

All three pillars of Turkish work and family life reconciliation exhibit high levels of incompleteness and contradictoriness, which could be gathered under four categories: (a) continued disconnect between the EU and Turkish rationale behind reconciliation policy-making, (b) vague budget regulations, (c) lack of state responsibility and (d) incentives for the reproduction of women's motherhood roles.

First and foremost, while the EU favours work and family life reconciliation for increased full-time female employment (Caracciolo di Torella and Masselot 2010; Stratigaki 2004), Turkey has relied on completely opposite logic. Turkey seeks to solve the work and family life conflict by reducing women's working hours through providing them the opportunity for part-time or flexible working arrangements,

11 In Turkey, ECEC services fall under the competence of the Ministry of Education or Ministry of Family and Social Policy. While the MoE is responsible for providing a comprehensive care places for children aged 0-2, the MFSP is responsible for children aged 3-6 (Ilkkaracan 2015).

10 The statement has been dropped from the Code in 2007 through the delegated legislation 24/1/2007 (Municipal Law No: 5393 bylaw 2). 
which ultimately traps them within the secondary labour market associated with low-paid, insecure jobs where the possibility of promotion is low. This contradictory policy paradigm of the Turkish political elite was also mentioned by the EU representatives. A senior policy expert from one of the social partners stated that:

“... Well, to be honest. Turkey has made legislative changes. Five years ago, none of the policy documents were covering work and family life conflict. Today they at least acknowledge the existence of the conflict. But this time, the solution is problematic. They solve the conflict by excluding women from the labour market, which for us is not a solution at all ..."

The two clauses of the Family and Dynamic Population Structure Protection clearly reflect this oppositional logic. To this, a very underdeveloped model of Turkish parental leave should be added. While the EU directive on parental leave grants a non-transferrable minimum three-month leave for fathers, Turkish rules mandate only ten days, and only then if the father is working in the public sector. The gap with the EU is even wider if the father is employed in the private sector, as they then have only a five-day leave. Last but not least, a very recent project administered by the Ministry of Labour and the Istanbul Chamber of Industry, called the 'Grandmother Allowance', aims to transfer childcare into the familial sphere. The Turkish state pays 450TL to grandmothers who care for their grandchildren. The Turkish Family Minister repeatedly underlines the importance of the project, as it provides financial support to the elderly alongside their pensions and provides more than one option regarding childcare to families. However, it widens the gap between the EU and Turkey. While the EU requires defamilialised care arrangements through institutionalised childcare, Turkey continues to keep it a familial duty, which is in accordance with the rationale of familialisation.

Furthermore, some legislative reforms and national targets have indicated very vague budget planning, which reduces their credibility. The 2005 Municipal Law, 2009 Strategic Plan of the Ministry of Education and the 10th Development Plan all aimed at expanding childcare spots. However, they all lacked an expenditure plan. None of the documents indicated how the government would finance the promised childcare. Similarly, the Family and Dynamic Population Structure Protection Plan ensured a full salary to employees in the cases of part-time work, but the law left the payment procedure vague. According to the law, the employee should receive the salary for the hours s/he worked from the employer and the rest from the unemployment fund. Yet, given the current Turkish economic structure, it is a total enigma as to whether the unemployment fund will be able to pay that gap or not (Toksoz 2015). As a result, these vague budget regulations have impaired the de-familialisation of work and family life reconciliation and overshadowed Turkey's Europeanisation process.

The third contradictory aspect of Turkish work and family life reconciliation policies made under EU influence is the fact that the Turkish government explicitly refuses the responsibility for childcare and paternal leave provisions. Article 88 of the Labour Code places the responsibility for childcare place provision on the private companies. Furthermore, the law does not include any measures regarding non-fulfilment of the requirement, and the state hardly monitors companies in this sense (Aldikacti-Marshall 2013). Under these circumstances, most companies prefer not to follow the regulation (Ilkkaracan 2015), which ultimately results in low childcare enrolment and low female employment rates in Turkey. In a similar vein, through the Grandmother Allowances project mentioned above, the Turkish government is again leaving the responsibility for childcare to the familial sphere, rather than transferring it to the market or to the state. Since the core attribute of defamilialisation is the transfer of caring responsibility from families either to state or to market, this legislation implies a very low level of defamilialisation and therefore, a very low level of Europeanisation. Moreover, until very recently, the regulations with respect to parental leave were under private companies' authority. The lack of a centralised national law has created cross-country variations, which influence the overall reform picture and dilute the defamilialisation impact of Turkish work and family life reconciliation policies. 
Finally, Turkish work and family life reconciliation policies both explicitly and implicitly emphasise the role of women as wives and providers of unpaid domestic work. Fathers have completely been excluded from the picture. The only law concerning fathers' roles in care is the second bylaw of the Labour Code, which was only added in 2015 with the omnibus bill. Even though the law covers paternal leave, the content is highly under-developed. This very unequal division of parental leave reaffirms women's roles as mothers, and concomitantly reproduces the traditional work/care dualism, where women are associated with domestic work and men with earning a living. Similarly, Article 88 of the same code conditions the existence of childcare facilities on the number of female workers, rather than the total number of workers. This also reproduces the traditional gendered division of labour patterns. Part-time work provisions granted to women through the Family and Dynamic Population Structure Protection Plan, too, reproduce women's motherhood roles rather than easing labour market participation. Although paying a full-time salary for part-time work would seem to acknowledge the importance of the formerly invisible caring work, it removes women from the labour market and encourages their motherhood roles, which also concerns the EU. A recent document, the 2016 Communication on EU Enlargement Policy Report, states:

Legislation on part-time work for working parents has been adopted. The lack of institutions and services to care for children, the elderly and sick people, including for long-term care, continue to hinder women's employment due to the gender bias for caring responsibilities. (COM, 2016: 60)

In summary, despite the high level of pressure coming from the EU and the long-standing desire for EU membership, the Turkish government has kept the traditional family model and the conservative division of labour alive. Under EU influence, Turkey has made numerous but patchy and half-hearted reforms, which ultimately have produced neither a reconciled work and family life nor an increased female employment rate.

\section{Conclusions}

Work and family life reconciliation policies have gained more and more importance over the last two decades within the EU agenda: these have successfully been reflected in Turkey's Accession Partnership Documents. This paper sought to illustrate the Europeanisation process of Turkey in the specific policy field of work and family life reconciliation from a gender perspective, and to identify the remaining disconnects between Turkish and EU work and family life reconciliation models. While seeking to answer the question of how much change has been brought about by Europeanisation, this paper found that, despite the high level of adaptational pressure coming from the EU, the reforms undertaken remain highly incomplete and contradictory. It can therefore be argued that Turkey's Europeanisation patterns of gender equality within work and family life reconciliation policy resonates most closely with "accommodation" among the five potential Europeanisation outcomes put forward by Radaelli (2003). This indicates a very modest policy change at the national level, but preserves the essential policy-making paradigm. Modest change at the legislative level, in isolation from the policy-making paradigm, unprecedentedly impaired Turkey's EU accession process. Especially in today's world, where Islamophobia is at its height, the ways in which Turkish women reconcile their work and family lives plays a significant role in the accession process. As observed by many scholars of EU studies, Turkey's accession process has been significantly impaired by Islam being the dominant religion in Turkey (Kalaycioğlu 2013; Yslmaz 2009). Here, it is important to note that Islam is not referred to as a theological system, but as a lifestyle (Usul 2008). In other words, what has been disliked and opposed about Islam has never been the ways in which Turks believe in or pray to God. Instead, the issue has always been the fact that Islam interferes in culture and politics (Yllmaz 2009), which links to the issues of women's rights. Women's dominance over men in the private sphere and their subordination in the public sphere (be it political participation or labour market participation) has become a symbol of Islam and calls to mind the terrorism associated with extremism. This ultimately 
serves to increase the already elevated scepticism towards Turkey. Accordingly, work and family life reconciliation remains an issue which requires further and more critical exploration.

Funding: This research received no external funding.

Conflicts of Interest: The authors declare no conflicts of interest.

\section{References}

Akser, Murat, and Banu Baybars-Hawks. 2012. Media and Democracy in Turkey: Toward A Model of Neoliberal Media Autocracy. Middle East Journal of Culture and Communication 5: 302-21. [CrossRef]

Aldikacti-Marshall, Gül. 2013. Shaping Gender Policy in Turkey: Grassroots Women Activists, the European Union and the Turkish State. Albany: State University of New York Press.

Arat, Yeşim. 2012. Rethinking Islam and Liberal Democracy: Islamist Women in Turkish Politics. Albany: SUNY Press. Aybars, Ayse Idil, and Dimitris Tsarouhas. 2010. Straddling two continents: Social Policy and Welfare Politics in Turkey. Social Policy \& Administration 44: 746-63.

Aydin-Duzgit, Senem, and Nathalie Tocci. 2015. Turkey and the European Union. Basingstoke: Palgrave Macmillan.

Bakirci, Kadriye. 2010. Turk hukukunda is ve aile sorumluluklarinin uzlastirilmasi: Uluslararasi hukuk ve $\mathrm{AB}$ hukuku cercevesinde bir degerlendirme. In Emek piyasasinda toplumsal cinsiyet esitligine dogru is ve aile yasamini uzlastirma politikalari. Edited by İpek Ilkkaracan. Istanbul: Mega Basim, pp. 59-86.

Borras, Susana, and Kerstin Jacobsson. 2004. The open method of coordination and new governance patterns in the EU. Journal of Public Policy 11: 185-208. [CrossRef]

Bugra, Ayşe, and Çağlar Keyder. 2006. The Turkish welfare regime in transformation. Journal of European Social Policy 16: 211-28. [CrossRef]

Bugra, Ayşe, and Burcu Yakut Cakar. 2010. Structural change, the social policy environment and female employment in turkey. Development and Change 41: 517-38. [CrossRef]

Caracciolo di Torella, Eugenia, and Annick Masselot. 2010. Reconciling Work and Family life in EU Law and Policy. Basingstoke: Palgrave Macmillan.

Dedeoglu, Saniye. 2012. Equality, Protection or Discrimination: Gender equality Policies in Turkey. Social Politics: International Studies in Gender, State E Society 19: 269-90.

Ecevit, Yildiz. 2010. Is ve aile yasaminin uzlastirilmasi baglaminda turkiye'de erken cocukluk bakimi ve egitimi. In Emek piyasasinda toplumsal cinsiyet esitligine dogru is ve aile yasamini uzlastirma politikalari. Edited by İpek Ilkkaracan. Istanbul: Mega Basim, pp. 87-114.

Esping-Andersen, Gøsta. 1990. The three Worlds of Welfare Capitalism. Cambridge: Polity Press.

Esping-Andersen, Gøsta. 1999. Social Foundations of Postindustrial Economies. Oxford: Oxford University Press.

Esping-Andersen, Gøsta. 2009. The Incomplete Revolution: Adapting to Women's New Roles. Malden: Polity Press.

European Commission. 2003. Regular Report from the Commission on Turkey's Progress towards Accession. Brussels: European Commission.

Ferrera, Maurizio. 1996. The southern model of welfare in social Europe. Journal of European Social Policy 6: 17-37. [CrossRef]

Grabbe, Heather. 2003. Europeanisation Goes East: Power and Uncertainty in the EU Accession Process. In The Politics of Europeanisation. Edited by Kevin Featherstone and Claudio M. Radaelli. Oxford: Oxford University Press, pp. 303-30.

Grutjen, Daniel. 2008. The Turkish Welfare Regime: An Example of the Southern European Model? The Role of the State, Market and Family in Welfare Provision. Turkish Policy Quarterly 7: 111-29.

Hantrais, Linda. 2004. Family Policy Matters: Responding to Family Changes in Europe. Bristol: The Policy Press.

Hemerijck, Anton. 2013. Changing Welfare States. Oxford: Oxford University Press.

Ilkkaracan, İpek, ed. 2010. Uzlastirma politikalari yoklugunda turkiye emek piyasasinda toplumsal cinsiyet esitligi. In Emek piyasasinda toplumsal cinsiyet esitligine dogru is ve aile yasamini uzlastirma politikalari. Istanbul: Mega Basim, pp. 7-20.

Ilkkaracan, İpek. 2015. Feminist politik iktisat ve kurumsal iktisat cercevesinde Turkiye'de kadin istihdam sorununa farkli bir yaklasim. In Gecmisten gunumuze Turkiye'de kadin emegi. Edited by Ahmet Makal and Gulay Toksoz. Ankara: Imge Kitabevi, pp. 169-84. 
Kalaycı̆ğlu, Ersin. 2013. The Turkish-EU odyssey and political regime change in Turkey. In Turkey and the EU: Accession and Reform. Edited by Gamze Avcı and Ali Çarkoğlu. London: Routledge, pp. 57-70.

Kantola, Johanna. 2010. Gender and the European Union. Basingstoke: Palgrave Macmillan.

Leira, Arnlaug. 2002. Working Parents and the Welfare State: Family Change and Policy Reform in Scandinavia. Cambridge: Cambridge University Press.

Lewis, Jane. 1992. Gender and the Development of Welfare Regimes. Journal of European Social Policy 2: 159-73. [CrossRef]

Lewis, Jane. 2009. Work-Family Balance, Gender and Policy. Cheltenham: Edward Elgar.

Lewis, Jane, and Ilona Ostner. 1991. Gender and evaluation of European social policies. In CES Workshop on Emergent Supranational Social Policy: The EC's Social Dimension in Comparative Perspective. London: Centre for European Studies.

Liebert, Ulrike. 2003. Gendering Europeanisation. Brussels: P.I.E.-Peter Lang.

Lohmann, Henning, and Hannah Zagel. 2016. Family policy in comparative perspective: The concepts and measurement of familization and defamilization. Journal of European Social Policy 26: 48-65. [CrossRef]

McDonald, Peter. 2000. The "Toolbox" of Public Policies to Impact on Fertility—A Global View. Canberra: Australian National University, unpublished manuscript.

McGlynn, Clare. 2005. Work, family and parenthood. In Labour Law, Work and the Family. Edited by Joanne Conaghan and Kerry Rittich. Oxford: Oxford University Press, pp. 217-36.

O'Connor, Julia S. 1993. Gender, Class and Citizenship in the Comparative Analysis of Welfare State Regimes: Theoretical and Methodological Issues. British Journal of Sociology 44: 501-18. [CrossRef]

Orloff, Ann Shola. 1993. Gender and social rights of citizenship: The comparative analysis of gender relations and welfare states. American Sociological Review 58: 303-28. [CrossRef]

Pateman, Carole. 1989. The Disorder of Women: Democracy, Feminism, and Political Theory. Stanford: Standford University Press.

Radaelli, Claudio M. 2003. The Europeanisation of Public Policy. In The Politics of Europeanisation. Edited by Kevin Featherstone and Claudio M. Radaelli. Oxford: Oxford University Press, pp. 27-56.

Schimmelfennig, Frank, and Ulrich Sedelmeier. 2005. The Europeanisation of Central and Eastern Europe. New York: Cornell University Press.

Stratigaki, Maria. 2004. The cooptation of gender concepts in EU policies: The case of "Reconciliation of work and family". Social Politics: International Studies in Gender, State \& Society 11: 30-56.

Taylor-Gooby, Peter. 1996. Paying for Welfare: The View from the Europe. Political Quarterly 67: 116-26. [CrossRef]

Toksoz, Gülay. 2015. Kalkinmada farkli yorungeler kadin istihdaminda farkli oruntuler isiginda Turkiye'de kadin istihdami. In Gecmisten gunumuze Turkiye'de kadin emegi. Edited by Ahmet Makal and Gulay Toksoz. Ankara: Imge Kitabevi, pp. 143-68.

Usul, Ali Resul. 2008. The Justice and Development Party and the European Union: from Euro-skepticism to Euro-enthusiasm and Euro-fatigue. In Secular and Islamic Politics in Turkey the Making of the Justice and Development Party. Edited by Ümit Cizre. London: Routledge, pp. 175-98.

Vural, Ipek Eren. 2011. Converging Europe: Transformation of Social Policy in the Enlarged European Union and in Turkey. Surrey: Ashgate Publishing Limited.

Yilmaz, Hakan. 2009. Turkish identity on the road to the EU: Basic elements of French and German oppositional discourses. In Turkey's Road to European Union Membership National Identity and Political Change. Edited by Susannah Verney and Kostas Ifantis. London: Routledge, pp. 79-92.

Y1lmaz, Gözde. 2016. From Europeanisation to De-Europeanisation: The Europeanisation Process of Turkey in 1999-2014. Journal of Contemporary European Studies 24: 86-100. [CrossRef]

(C) 2019 by the author. Licensee MDPI, Basel, Switzerland. This article is an open access article distributed under the terms and conditions of the Creative Commons Attribution (CC BY) license (http:/ / creativecommons.org/licenses/by/4.0/). 